\title{
RAWLS AND TORT LAW: A CRITIQUE OF RIPSTEIN
}

\section{RAWLS Y RESPONSABILIDAD CIVIL: UNA CRÍTICA DE RIPSTEIN}

Leandro Martins Zanitelli*

\begin{abstract}
The article challenges Arthur Ripstein's theses on the place of private law (and tort law in particular) in John Rawls' theory of justice. According to Ripstein, Rawls' theory of justice grants private law a certain independence by exempting it from the distributive injunctions of the principles chosen in the original position. This conclusion has two bases, one negative and the other positive. On the negative side of the argument, Ripstein claims that Rawls' original position does not lend itself to guiding the design of institutions, especially those institutions with a deontological structure such as tort law. On the positive side, Ripstein resorts to the idea of a division of responsibility between citizens and social institutions (an idea that Rawls presents in "Social Unity and Primary Goods") to demonstrate Rawls' commitment to a pre-institutional conception of ownership and to the independence of private law that would ensue. The article argues that Ripstein is wrong in neglecting the role of the original position and the principles chosen in that position and exaggerates the consequences for private law of the division of responsibility between citizens and institutions.
\end{abstract}

KEYwORDs: tort law; Rawls; Ripstein; distributive justice; corrective justice

\section{RESUMEN}

El artículo cuestiona las tesis de Arthur Ripstein sobre el lugar del derecho privado (y, en particular, del derecho de daños) en la teoría de la justicia

* Adjunct Professor at the Federal University of the State of Minas Gerais. Correo electrónico: leandrozanitelliufmg.br

The author thanks two anonymous reviewers of Revista Chilena de Derecho Privado for their critiques and suggestions about an earlier version of the article. All remaining errors are mine.

Recepción: 2021-03-25; aceptación: 2021-05-17. 
de John Rawls. Según Ripstein, la teoría de la justicia de Rawls otorga al derecho privado una cierta independencia, al no someterlo a los mandatos distributivos de los principios elegidos en la posición original. Esta conclusión tiene dos bases, una negativa y otra positiva. En el lado negativo del argumento, Ripstein afirma que la posición original de Rawls no se presta a guiar el diseño de instituciones, especialmente instituciones, como la ley de responsabilidad civil, con una estructura deontológica. En el lado positivo, Ripstein recurre a la idea de una división de responsabilidades entre ciudadanos e instituciones sociales (idea que Rawls presenta en el artículo Social Unity and Primary Goods) para demostrar el compromiso de Rawls con una concepción preinstitucional de propiedad y con la independencia del derecho privado que se derivaría. El artículo sostiene que Ripstein se equivoca al descuidar el papel de la posición original y los principios elegidos en esa posición, así como exagera las consecuencias para el derecho privado de la división de responsabilidades entre ciudadanos e instituciones.

Palabras Clave: derecho de daños; Rawls; Ripstein; justicia distributiva; justicia correctiva

In an article published some years ago, Arthur Ripstein advocates an original interpretation of John Rawls' theory of justice ${ }^{1}$. Ripstein's attention is focused on private law and tort law in particular. Contrary to the idea that Rawls' conception of justice- as fairness- would subordinate private law to distributive objectives ${ }^{2}$, Ripstein claims that the division of responsibility between social institutions and citizens (a division that Rawls alludes to in "Social Unity and Primary Goods" 3 ) implies a conception of private law that, while not libertarian (because it is compatible with the accumulated

${ }^{1}$ The article is "The Division of Responsibility and the Law of Tort". RIPSTEIN (2004). In this article, I deal exclusively with Ripstein's analysis of the implications of Rawls' theory of justice for private law in general and, in particular, for tort law. Therefore, I am not concerned with more recent works, such as Force and Freedom: Kant's Legal and Political Philosophy (Cambridge, MA: Harvard University Press, 2009) and Private Wrongs (Cambridge, MA: Harvard University Press, 2016), in which Ripstein develops a peculiar conception of private law based on Kant's Rechtslehre and without further references to Rawls' writings.

${ }^{2}$ I have myself defended this idea over the past few years - see, for example, ZANITELLI (2019). See also Scheffler (2015) and Freeman (2018, cap. 5).

${ }^{3}$ Included in Collected Papers. Rawls (1999a). 
results of voluntary and involuntary transactions and distributive standards), is also incompatible with private law as mere instrument to meet distributive demands. According to Ripstein, justice, as Rawls conceives it, requires private law to enjoy a certain independence ${ }^{4}$.

Ripstein's argument consists of three parts. In the first two, he endeavors to demonstrate that the place of tort law (the area of private law that he primarily envisions) in Rawls' theory of justice cannot be determined from the original position - i.e., Rawls' version of the moral point of view from which the principles for the basic structure of society are justified. Opposing the idea that the choice of principles in the original position has anything to contribute to tort law and private law as a whole, Ripstein makes two claims. The first is that the original position is a mere rhetorical device, incapable -as such- of any guidance on the design of institutions that is not already predetermined by how that position is characterized and by the substantial decisions that this characterization involves. The second claim is that if -in opposition to the preceding claim-the original position had any heuristic role, it would nonetheless be inappropriate to consider the principles chosen in that position for private law purposes since the deliberation of the parties in the original position is consequentialist and, therefore, incompatible with private law's deontological nature. Lastly, in the third part of his argument, Ripstein puts aside the original position, seeking to define the place of private law in Rawls' theory of justice based on the idea of a division of responsibility between citizens and institutions. According to Ripstein, this division of responsibility implies an institutional property regime (which includes tort law and, presumably, contract law) structured in a fashion alien to the distributive demands stemming from the principles of justice, such as justice as fairness, but whose accumulated results may have to be corrected to meet these same demands.

The present article is divided into three sections with each addressing one part of Ripstein's argument. My conclusion is that Ripstein is correct in stating that the division of responsibility to which Rawls alludes -and the conceptions of person and primary goods that underlie this divisionimply pre-institutional property rights, that is, rights independent of the basic structure molded in accordance with the principles chosen in the original position. These pre-institutional property rights are, however, too indeterminate for the purpose of justifying private law. Thus, contrary to what Ripstein claims, the general contours of a Rawlsian regime of tort law and private law in general must conform to the distributive prescriptions of the conception of justice -justice as fairness- which, according to Rawls, would be chosen in the original position.

\footnotetext{
${ }^{4}$ Ripstein (2004), pp. 1814-1815.
} 


\section{ORIGINAL POSITION \\ AS A MERE RHETORICAL DEVICE}

The first thesis Ripstein posits is that the place of tort law (and, by extension, private law in general) in Rawls' theory of justice cannot be determined from the original position. This thesis is supported by two arguments. First, the original position per se does not lend itself to support conclusions on the tort law regime (for example, on whether and to what extent tort liability should be conditional on fault), since it consists of a mere rhetorical device. This is the argument that will be examined in this section.

Ripstein argues that tort law is not guided by the choice of parties in Rawls' original position and that such position is devoid of substance. As a mere rhetorical device, there is nothing that can be constructed through the original position. All the burden of justification falls on rules that predate this position and are incorporated into it only for the purpose of explanation. Since these norms are of substantive importance, it is erroneous to believe that the original position itself - that is, regardless of the norms that infuse it with content- is the basis for resolving policy issues.

"It does a serious disservice to Rawls' many contributions to political philosophy to imagine that he means to be offering [via the original position] anything resembling an algorithm for determining how society's institutions should work" 5 .

Ripstein exemplifies the merely formal nature of the original position in the case of tort law ${ }^{6}$. The choice between negligence and strict liability regimes is a choice between a regime that favors freedom (the former) and one that favors security (the latter). The question of which of these regimes would be chosen by the parties in the original position depends, therefore, on which of the interests involved -freedom or security- is decisive to the choice. But for Ripstein, this question cannot be answered solely with the resources of the original position, that is, exclusively based on the idea of a deliberation made under conditions of ignorance that is, as such, impartial. In the original position, the parties are driven by interests grounded in certain normative considerations. Therefore, depending on the relative weight that these considerations attribute to the interests for freedom and security, the original position can be constituted in such a fashion as to lean toward one tort law regime or the other. This "game of marked cards" has, of course, no force of justification. Its role is simply

\footnotetext{
${ }^{5}$ Ripstein (2004), p. 1812.

${ }^{6}$ Ripstein (2004), p. 1819.
} 
to highlight the normative conflict of substance -in this case, the conflict between the norms of security and freedom.

Ripstein is correct to deny that the original position is an algorithm for social institutions, construed as any question of institutional design -such as the choice between negligence and strict liability regimes- must be answered accordingly with the prospective decision under the conditions of the original position. Yet, the reason the original position cannot be treated as an algorithm in this sense is that it is designed with a view toward deciding not on institutional design issues in general, but on one of those issues in particular: determining what Rawls calls the basic structure of society. This structure is made up of the primary social institutions whose effects on citizens' expectations are most notable. Rawls explains:

"The intuitive notion here is that this structure contains various social positions and that men born into different positions have different expectatives of life determined, in part, by the political system as well as by economic and social circumstances. [...] It is these inequalities, presumably inevitable in the basic structure of any society, to which the principles of social justice must in the first instance apply"?.

The reason that the principles chosen in the original position are principles for the basic structure of society -principles with which this structure, in its entirety, must conform- is not therefore fortuitous. Rawls has in mind the impact of society's basic institutions on citizens' expectations, that is, how these institutions determine the distribution of the benefits and burdens of social cooperation. There are at least two problems, then, in resorting to the original position -as Rawls conceives it- to resolve specific issues of institutional design, such as the choice between negligence and strict liability regimes. The first is that, by focusing on an issue like this, we neglect the fact that social institutions operate in tandem, that is, that these institutions constitute a relatively articulated whole. The second problem is that the information restrictions characteristic of Rawls' original position may not be defensible when it comes to a choice other than the basic terms of social cooperation. For matters alien to the basic structure of society, considerations that are necessarily foreign to the deliberation of the parties in the original position -such as certain valuation considerations or even the simple satisfaction of non-generalizable interests-may prove pertinent.

Yet, these observations do not place us squarely before Ripstein's objection to the original position. Although the caveat is made about the

\footnotetext{
${ }^{7}$ Rawls (1999b), p. 7.
} 
uniqueness of the choice to be made -among the principles regulating the basic structure of society-it is still necessary to face the allegation that the original position is nothing more than a rhetorical device, that is, that no argument itself in favor of principles of justice can be deduced from this position since its design apparently already makes use of rules that determine the outcome of the deliberation - a result that would, therefore, need to be justified independently.

Ripstein bases this allegation of redundancy on a passage in which Rawls states that "for each traditional conception of justice there exists an interpretation of the initial situation in which its principles are the preferred solution ${ }^{8}$." But, Ripstein claims that if the initial situation ${ }^{9}$ is malleable in such a way that it does not rule out any of several traditional conceptions of political justice, starting with different versions of utilitarianism -i.e. if everything depends on how this initial situation is delineated- then it does seem that the simple fact that justice as fairness is the conception of justice chosen under a particular characterization of the initial situation (i.e. Rawls' original position) says nothing about the relative merit of this conception of justice vis-à-vis others.

That said, it is erroneous to infer that the initial situation is malleable in the sense Ripstein cogitates -that is, that it is licit to manipulate the initial situation to arrive at a conception of justice justified on independent grounds. This is not, at least, how Rawls treats the initial situation and the original position, that is, the particular interpretation of the initial situation defended in TJ. In a passage immediately preceding the one transcribed above, Rawls says:

"But the question of justification is settled, as far as it can be, by showing that there is one interpretation of the initial situation which best expresses the conditions that are widely thought reasonable to impose on the choice of principles yet which, at the same time, leads to a conception that characterizes our considered judgments in reflective equilibrium. This most favored, or standard, interpretation I shall refer to as the original position"10.

As such, for Rawls the conditions for choosing principles of justice that characterize each of the possible versions of the initial situation can

\footnotetext{
${ }^{8}$ Rawls (1999b), p. 105.

${ }^{9}$ Rawls designates as initial situation any point of view from which principles of justice are chosen. The original position, that is, the point of view from which the principles of justice are chosen, is a particular version of this situation.

${ }^{10}$ Rawls (1999b), p. 105.
} 
be considered more or less reasonable. Therefore, the reasons for preferring the original position over other versions of the initial situation -for example, over versions under which some utilitarian principle would be chosen- are not related solely to the result of the choice, that is, to the merits of justice as fairness compared to other conceptions of justice. In contrast, it is true that the argument in favor of the original position (as the most reasonable initial situation) is not at all insensitive to the outcome of the choice, that is, to the question of whether the original position leads to a conception of justice in harmony with our intuitions. In another passage, Rawls also refers to the possibility of revising the original position in view of the chosen conception of justice:

"In searching for the most favored description of this situation [the initial situation] we work from both ends. We begin by describing it so that it represents generally shared and preferably weak conditions. We then see if these conditions are strong enough to yield a significant set of principles. If not, we look for further premises equally reasonable. But if so, and these principles match our considered convictions of justice, then so far well and good. But presumably there will be discrepancies. In this case we have a choice. We can either modify the account of the initial situation or we can revise our existing judgments, for even the judgments we take provisionally as fixed points are liable to revision. By going back and forth, sometimes altering the conditions of the contractual circumstances, at others withdrawing our judgments and conforming them to principle, I assume that eventually we shall find a description of the initial situation that both expresses reasonable conditions and yields principles which match our considered judgments duly pruned and adjusted. This state of affairs I refer to as reflective equilibrium (footnote omitted)" 11.

Even if we decide to "go backwards" that is, if dissatisfaction with the resulting conception of justice convinces us to change the conditions of the choice, it is not necessary to conclude that there is a "short circuit" i.e., that these conditions are changed or -worse yet- manipulated to give rise to an independently preferred conception of justice. The question of the initial situation in Rawls is that of the most reasonable conditions for the choice of principles of justice. It is in these terms -those of the most reasonable conditions of choice- that the merits of different versions of the initial situation are compared. Thus, if a certain version of the initial

${ }^{11}$ RaWls (1999b), p. 18. 
situation is ultimately rejected by the incompatibility between the conception of justice that results from it and our convictions, the reasons for replacing one version of the initial situation with another cannot be based solely on the outcome of the choice. It would be odd to say that certain conditions of choice are more reasonable only because of what is chosen under those same conditions ${ }^{12}$.

\section{ORIGINAL POSITION AND CONSEQUENTIALISM}

According to Ripstein, another reason that the law of tort remains outside deliberations in the original position has to do with a sort of structural incompatibility. While tort law is deontological in nature, the original position subjects the design of institutions solely to the consequences to which these institutions give rise. Thus, an incompatibility exists between the deontological nature of tort law and the institutional consequentialism that arises from the conditions of choice in the original position.

"This deontological structure of tort doctrine poses an immediate difficulty for any explication or adjudication of it within the structure of a Rawlsian contract argument. The problem is that this structure will always be invisible from the point of view of the contract argument. Parties behind the veil of ignorance have an interest in being free of injury, especially bodily injury, and an interest in being free to engage in activities that have the potential to injure others. Parallel to these two interests, but distinct from

12 Anthony Simon Laden (2014) defends an interpretation according to which Rawls' constructivism is merely rhetorical, since Rawls' metaethical solution (a "self-effacing" solution, that is, which is metaethical without being it) is that of reflexive equilibrium. In other words, according to Laden, Rawls would have relieved himself of the burden of justifying his conception of justice by the procedure of the original position, appealing instead to shared beliefs (thus reducing the original position to the methodological role of bringing to light the implications of those beliefs). The sense of "rhetorical" in the case of Laden is not, however, that of a manipulative persuasion device. "In adjusting what I say to my particular audience, I attend to their specificity and position, and thus reach out to them, trying to find a way to move toward where they are, rather than insist they come to me. Moreover, this willingness to adjust to my audience is itself persuasive, not in the sense that it gives me access to the levers by which I can more effectively manipulate them, but because by showing my respect for where they stand in the way I choose to address them, I give them reason to trust me and reach out to me". LADEN (2014), p. 66. My impression is that Ripstein underestimates the role of the original position in Rawls' theory of justice because he understands that position as manipulative in the sense that Laden rules out in the above passage. 
them, is a pair of interests in receiving compensation if injured, and in spending as little as possible to compensate others. In addition to these four interests, parties will also have an interest in avoiding what economists call transaction costs - they will want to use no more resources than are necessary to achieve the desired levels of liberty, security, compensation, and economy. Indeed, as rational choosers concerned to protect their own means with which to pursue their own purposes, they must be prepared to forego liberty or security if the price is too high"13.

An initial response to this argument is that it misinterprets the original position in supposing that it proposes to account for certain social institutions or practices. This intent would be doomed to failure whenever the practice in question boasted a kind of structure to which the original position is necessarily insensitive. The problem is that the deliberation in the original position is not a deliberation on the best interpretation of current institutions, but on the principles to which the main institutions (those that largely determine citizens' expectations regarding the distribution of the benefits and burdens of social cooperation) of a just society must conform. From this perspective, the fact that existing institutions are not supported by the principles chosen in the original position is a reason to reform them, no to endeavor to support these institutions on any other grounds ${ }^{14}$.

Another question is whether there is, in fact, the alleged incompatibility between the consequentialism of the original position and the deontological character of tort law. The fact that the choice in the original position is oriented towards the consequences of principles and institutions is an obstacle to the question of whether among the institutions of a wellordered society (that is, a society whose institutions meet the principles chosen in the original position) tort law as we know it exists. Given their consequences, why couldn't the principles chosen in the original position be realized through an institutional arrangement that includes tort law? To exemplify, suppose that Rawls is correct in stating that the conception of justice chosen in the original position includes a principle such as the difference principle ${ }^{15}$ and that, to satisfy this principle, a society

${ }^{13}$ Ripstein (2004), p. 1821.

${ }^{14}$ This, in summary, is the argument with which Kordana y TABACHNick (2006a).

${ }^{15}$ RAwLS (2001), pp. 42-43, enunciates the two principles of his conception of justice as follows: "(a) [e] ach person has the same indefeasible claim to a fully adequate scheme of equal basic liberties, which scheme is compatible with the same scheme of liberties for all ; and (b) [s]ocial and economic inequalities are to satisfy two conditions: first, they are to be attached to offices and positions open to all under conditions of fair equality of opportunity; 
must choose to deal with accidents through tort law or social insurance. Would it not be possible, depending on the circumstances, for tort law to be chosen? That is, compared to social insurance wouldn't tort law be part of an institutional arrangement under which the expectations of the worst-off citizens are the highest?

Perhaps the conclusion regarding the incompatibility between the consequentialism of the original position and the law of tort can be confirmed at least as regards Rawls' conception of justice ${ }^{16}$ for the very reason that this conception includes a principle of maximization as the difference principle ${ }^{17}$. The problem is that a principle such as this makes it possible, within certain limits (in the case of justice as fairness, the limits arising from the principles of basic liberties and fair equality of opportunities), for the institutions of the basic structure to be arranged to maximize the expectations of the worst-off citizens. This maximization purpose appears incompatible, however, with non-consequentialist considerations guiding the design of certain institutions. Therefore, a law of tort governed by the difference principle could not be a law of tort as we know it, that is, an area of deontologically structured regulation in which concepts such as those of duty and cause have a prominent place. Instead of the question of whether the defendant has breached a duty and caused the harm suffered by the plaintiff, a tort law regulated by the difference principle would deal only with the consequences of civil liability. The question, then, would be how to delineate the tort regime in such a way that, together with the other institutions of the basic structure of society, the expectations of the worst-off citizens are as high as possible. From this perspective, questions concerning duty and the cause of harm would seem irrelevant ${ }^{18}$.

But the fear that a law of tort guided by justice as fairness could end up "colonized" by the difference principle (that is, that the objective of

and second, they are to be the greatest benefit of the least-advantaged members of society". The second part of the second principle ("b") is the difference principle.

${ }^{16}$ The incompatibility would be, in this case, not between tort law and the original position itself, but between tort law and the conception of justice that, according to Rawls, would be chosen in that position. Obviously, if Rawls is right and justice as fairness is, in fact, the conception of justice that the parties in the original position would prefer, this would be the same. Otherwise, it would be necessary to verify whether any other conception of justice arising from the original position is afflicted by the same problem mentioned above, as well as whether this is a mere contingency or, as Ripstein wants, a problem whose root is in the selection procedure itself.

${ }^{17}$ That the best interpretation of the difference principle is, in fact, the one that treats it as a maximization principle is a question that we can set aside here. For considerations similar in content to the paragraph above, see SCHEFfler (2015), pp. 222-225.

${ }^{18}$ For a similar criticism addressed to the economic analysis of tort law, see Coleman (1988). 
maximizing the expectations of the worst-off citizens overrunning the deontological structure of tort law) ignores how restricted the scope of application of the principles chosen in the original position is. The mistake here is to assume that an area of regulation such as tort law is either part of what Rawls calls the basic structure or it is not, so that, once belonging to the basic structure, the entirety of its rules must conform to the principles chosen in the original position. It is clear, however, that this interpretation hypostasizes tort law (as well as any other rules to which the same treatment applies). From the point of view of a conception of justice limited to the basic structure of society, what matters is not the -historically contingentway in which the legal system is usually segmented, but certain rules for social cooperation and the distribution of its respective benefits and burdens. It is perfectly possible to conclude, in this vein, that certain parts of the tort regime, and only they, have to meet the distributive demands of justice as fairness, because those are the parts of that regime that have a considerable impact on the worst-off citizens' expectations.

Since subjecting tort law to justice as fairness does not mean subjecting each of its details to this conception of justice, the difference principle can be applied to tort law without depriving it of its deontological character and thus without supplanting or, at best, disfiguring ideas such as those of duty and cause. Whether this is actually true, of course, is something that can only be said considering the circumstances of application of that principle. To reject the thesis of a categorical incompatibility between the consequentialism of the original position and tort law, in any case, suffice it to note that the application of the principles chosen in that position does not imply that the totality of tort law (as well as its judicial application) should be guided by consequentialist reasons.

Lastly, I would like to address the alleged consequentialism of the original position. According to Ripstein ${ }^{19}$ :

"Thomas Pogge underscores this point by describing the contractarian approach as 'consequentialist,' because the contract argument shares with familiar forms of consequentialism its exclusive focus on outcomes. Indeed, as Pogge points out, in the one place that Rawls imagines the parties considering a case that Locke, Rousseau, or Kant might have taken up, that is, the topic of punishment, he presents them as reasoning in just this sort of way. Rawls considers the possibility that, were the proliferation of firearms a sufficiently serious threat to personal security and social stability, citizens might adopt a regime of strict liability for mere possession of a firearm.

${ }^{19}$ Ripstein (2004), pp. 1822-1823. 
Anyone caught in violation of the prohibition would be subject to criminal punishment, even though they presumably intended to do no harm, and perhaps cause no harm and, moreover, may not have even been aware of their possession of it. A number of commentators, notably Thomas Pogge and George Fletcher, have pointed out that this is among the least satisfactory aspects of Rawls' argument. And it is unsatisfactory for a completely straightforward reason: The parties are concerned only with outcomes, and, because they are concerned only with outcomes, must be prepared to trade liberty off against security in whatever way will best protect their interests (footnotes omitted)".

There are two ways in which the original position can be associated with a consequentialist morality which, in my view, are not sufficiently differentiated in the above passage. In one, the original position is deemed consequentialist because, as described, the considerations that determine the choice of principles are necessarily consequentialist. In the other, consequentialism is only present in the application of the principles chosen in the original position, that is, in the design of the institutions of the basic structure. Although one consequentialism does not exclude the other, we should not assume that one implies the other. When referring to the control of firearms, Ripstein seems to have a consequentialist view of the application of the principles. Yet, the "parties" to which the end of the passage refers can be construed as those in Rawls' original position, whose deliberation is on the principles themselves rather than their application ${ }^{20}$. This difference between consequentialism in the justification of the principles (that is, in the deliberation of the parties in the original position) and in their application to the institutions of the basic structure is important because, even if the choice of principles in the original position is consequentialist, Ripstein's argument for disregarding the original position would only be successful if the application of the principles chosen in that position had also to be based exclusively on consequences.

There is, however, one way in which the deliberation of the parties in the original position is consequentialist. Rawls characterizes contractors in their original position as agents driven by three interests (which he designates as higher-order interests): interest in the development and exercise of the two moral capacities; capacity for a conception of good and for a sense of justice; and interest in the realization of a certain conception of

${ }^{20}$ Thomas Pogge's (1995) article quoted by Ripstein, on the other hand, clearly deals with the problem of application. 
good $^{21}$. Different conceptions of justice are assessed in the original position, therefore, according to their consequences for these interests. The additional stipulation of mutual indifference ${ }^{22}$-that is, that each contractor is solely concerned with their interests- also implies that the choice of principles is not subject to deontological limits (which does not mean that Rawls' theory of justice ignores these limits, but rather that they are previously incorporated into the conditions of the original position, so that they do not interfere with the parties' decision).

The fact that the deliberation in the original position is guided by such higher-order interests -and that the principles chosen are, therefore, principles in line with them-does not imply, however, that the application of these principles also obeys consequentialist considerations. Rawls pays little attention to the problem of applying principles (in comparison to the attention he gives to the problem justifying them). In $\S 31$ of $A$ Theory of Justice $e^{23}$, we learn only that this application begins in the second of a sequence of four stages (the first stage is the choice of principles in the original position), that of the constitutional convention. In late writings (for example, in Political Liberalism ${ }^{24}$ ), Rawls goes on to argue that the application of principles of justice to constitutional and basic justice matters is regulated by a principle of public reason. None of this is very illuminating about the nature -consequentialist or not- of the reasons at the basis of the application of the principles of justice as fairness to the institutions of the basic structure. Bearing in mind, however, the content of some of the principles of the conception of justice defended by Rawls, it is at least plausible that the application of these principles obeys, at least in part, non-consequentialist considerations (or that are not consequentialist in a more than trivial sense). For example, certain basic rights such as the constitutional freedom of conscience and belief can be justified simply because they comply with the basic liberties principle, that is, regardless of any state of affairs resulting from the safeguard of those rights ${ }^{25}$.

${ }^{21}$ Rawls (1996), pp. 73-74.

${ }^{22}$ Rawls (1999b), p. 125.

${ }^{23}$ RAwls (1999b).

${ }^{24}$ Rawls (1996).

${ }^{25}$ The problem that Pogge (1995) alludes to is that, in non-ideal conditions -that is, in conditions in which disobedience to the law is considerable- basic freedoms can be threatened by the action of both the state and other citizens. For Pogge, the application of the principle of basic liberties in such circumstances imposes a consequentialist calculation: certain legal restrictions on freedom would be justified if, by inhibiting offenses against freedoms practiced by other citizens, they result in a total number of violations lower than those that would occur if those restrictions were not imposed. Correct or not, note that this argument is limited to the hypothesis of applying the principles chosen in the original position under non-ideal conditions. Pogge does not say, therefore, as Ripstein 
In the realm of tort law, while the regime may have little relation to the parts of justice as fairness (as the principle of basic liberties) it is more likely to be applied in a non-consequentialist manner. If, in the case of tort law, the principle at stake is really the difference principle -that is, if the considerations on the law of tort's structural features and its very suitability in comparison with alternative measures, such as social insurance, are exclusively associated with the difference principle- then it is quite possible that the considerations in question are consequentialist in the sense of having in mind the impact of tort law on the expectations of the worst-off citizens. As noted previously, however, it is a mistake to assume that the consequentialist nature of the reasons that eventually lead to including tort law among the institutions of a well-ordered society and that determine the most important characteristics (important for the expectations of citizens with regard to distribution of primary goods) under the tort law regime are incompatible with the deontological structure that characterizes this area of law.

\section{DIVISION OF RESPONSIBILITY AND TORT LAW}

According to Ripstein, the belief that the original position has nothing to contribute to the contours of a tort law regime does not mean that Rawls' theory of justice lacks resources to deal with this area of law. A justification for tort law can be found in the idea of the division of responsibility between social institutions and citizens that Rawls presents in the article "Social Unity and Primary Goods"26.

In that article, Rawls highlights the difference between justice as fairness and teleological conceptions of justice. Teleological conceptions of justice start from a certain conception about the good of the citizens, defining the just according to this conception (as occurs, for example, in utilitarianism, where the just is defined as the maximization of total or average utility $)^{27}$. By using the original position, Rawls' theory of justice refrains from appealing to a robust conception of good, contenting itself rather with a partial conception of good that includes the idea of primary goods as those necessary for the realization of the higher-order interests.

Without involving a complete conception of good, justice as fairness is necessarily insensitive to the extent to which each citizen's good is

seems to understand, that principles justified through the device of the original position are necessarily (that is, even under ideal conditions) applied in a consequentialist way.

${ }^{26}$ RAWLS (1999a).

${ }^{27}$ On teleological conceptions of justice, see RAWLS (1999b), pp. 21-22. 
achieved. It is a conception of justice that is limited, therefore, to defining fair terms for social cooperation under which each citizen must pursue his/her ends. The division of responsibility referred to by Rawls is none other than the division between the responsibility of the institutions of the basic structure for ensuring fair terms of social cooperation and the responsibility of each citizen for the realization of their own $\operatorname{good}^{28}$.

Ripstein's original thesis is that this same division of responsibility, which limits what citizens can legitimately claim from social institutions, implies a system of tort law independent from the distributive objectives associated with the conception of justice chosen in the original position. In sum, the argument is as follows: the same idea of each citizen's responsibility for the realization of her own ends that serves as a limit to the demands that can be made on social institutions also limits what citizens are allowed to do to each other. Just as I am not able to demand from institutions that the satisfaction of my preferences, whatever they may be, be assured to me, it is equally not permissible for me to use what belongs to others to achieve my purposes. The citizen who endangers the lives of others or violates their property to achieve her ends acts as unreasonably as the one who claims from social institutions more resources than those due to him under fair terms of social cooperation.

"Absent contractual arrangements, or some peculiar set of private arrangements deemed by law, such as those between parents and children, others can make no demands on my person or property. Conversely, I can make no demands on theirs. To allow me to make further demands on others -to allow me, for example, to injure them, or damage their goods as I go about my pursuit of my own plan of life-would be inconsistent with the idea that each of us has a special responsibility for his or her own life, because it would allow me to displace the costs of my own pursuit of my own plan of life on to others. I also cannot make further demands on others by using what is theirs in pursuit of purposes that they do not share, borrowing their property without their consent, or tricking them into doing something on my behalf. In the same way, to allow others to make further demands on me would saddle me with the responsibility for how well those other people find that their lives go"29.

${ }^{28}$ Rawls (1999a), p. 371, clarifies that this division of responsibility is based on the concept of a person incorporated into justice as fairness: "[t]his division of responsibility relies on the capacity of persons to assume responsibility for their ends and to moderate the claims they make on their social institutions in accordance with the use of primary goods".

${ }^{29}$ Ripstein (2004), p. 1833. 
But what, after all, is the relationship between the idea of division of responsibility -as Ripstein interprets it- and tort law? More precisely, why would the division of responsibility imply a regime of tort law immune to the distributive injunctions characteristic of a conception of justice such as justice as fairness? Note that, for Ripstein the division of responsibility is one of the foundations of Rawls' theory of justice. This division, along with other ideas that shape the original position -such as the idea of free and equal citizens- is one of the assumptions of Rawls' theory of justice because a non-teleological theory of justice concerned only with defining fair terms of social cooperation necessarily treats these terms as limits to what citizens can claim from each other in what comes to justice.

Given that the division of responsibility also implies, as Ripstein suggests, that citizens refrain from pursuing their ends by misusing what belongs to other people, that division therefore imposes a system of tort law through which that objective -that no citizen interfere illegitimately with what belongs to another- is achieved. For Ripstein, therefore, tort law -as a necessary implication of the division of responsibility that Rawls' original position presupposes-is logically prior to the principles of justice chosen in that position.

One can agree with Ripstein that a non-teleological conception of 100 justice like Rawls' must really be based on property rights -rights that are not, therefore, mere implications of the principles that constitute the conception in question. In other words, a conception of justice occupied exclusively with defining fair terms of cooperation between citizens who pursue different ends is inevitably committed to property rights that enable these citizens -under whatever terms the conception of justice itself stipulates as fair-to pursue their ends (whatever they may be). There is a case, therefore, in which a conception of justice like Rawls' cannot dispense with property rights that are logically prior to -and independent of- the principles of that conception.

The difficulty with Ripstein's thesis lies in the fact that it implies that these property rights prior to the principles of justice as fairness necessarily involve a system of tort law. While it is true, as noted above, that the idea of fair terms of cooperation implies certain rights of exclusion -that is, that citizens can pursue their ends with the resources at their disposal without being subject to interference from other citizens. However, there also seems to be no reason to claim that this "free space" against interference must be ensured through the compensatory rights that characterize a tort law regime. Why should we not limit ourselves, if appropriate, to ensuring that each person uses what is his or her own through a reasonably effective criminal system -or through a reasonably effective criminal system combined with indemnity rights, albeit ones different from those 
usually granted by a system of tort law organized as a system of corrective justice? One question, in short, is whether the property rights to which Rawls' conception of justice is necessarily committed are not too abstract to validate Ripstein's thesis about the necessary relation between division of responsibility and tort law.

Ripstein could well reply that the division of responsibility depends on the fact that every citizen whose resources are improperly used or destroyed by the action of another person is fully compensated and that this duty of compensation falls on the author of the undue interference. Suppose that B causes an accident while driving your car negligently and that a vehicle belonging to another person, A, is destroyed. Suppose also that, in such cases, the law is content to impose a fine on B (or, depending on the circumstances, to imprison him), without offering A compensation (or, at least, not complete compensation) for the loss of the vehicle and other damages resulting from the accident. The division of responsibility would be compromised, in such a hypothesis by the fact that B's action unduly deprived $\mathrm{A}$ of what belonged to him and by the refusal (by the legal system) to give A the right to complete reparation.

The argument in the previous paragraph reflects the error in Ripstein's description of the idea of the division of responsibility and tort law. Note that the argument rests on a premise that fair terms of cooperation necessarily imply that A's ownership rights to the car destroyed in the accident includes that of full reparation in the event of negligent damage caused by someone else. Imagine a system of property rights in which ownership of a car does not include that right to reparation; that is, a system in which the claim for reparation against wrongfully caused damage is not included among the claims, liberties and other prerogatives that make up the property right. In such a hypothesis, we simply would not be allowed to claim that, in causing the accident, B illegitimately interfered with A's resources, since those resources -in particular, A's right over her car- do not include the claim to be compensated for damages caused by someone else.

The question here is not whether a property rights system such as the one described above is desirable or not, but whether the system in question is incompatible with the idea of division of responsibility. It is not. A system of property rights that does not include tort law can still be a system that allocates rights among citizens and enforces the division of responsibility in the way idealized by Rawls and Ripstein. It is a system in which institutions are responsible for defining fair terms of cooperation under which each citizen is responsible for the realization of their own ends (Rawls). It is also a system under which this division of responsibility is enforced by prohibiting each one from being illegitimately deprived of what is her 
own by the action of another (Ripstein). Under this system, there may be several ways in which the car destroyed in the accident belonged to $\mathrm{A}$ and in which, therefore, $\mathrm{A}$ is protected against unlawful interference from others with regard to the vehicle. This unlawful interference would not, however, include the accident culpably caused by $\mathrm{B}^{30}$.

In short, Ripstein is correct to say that the fundamental idea of division of responsibility of a conception of justice like Rawls' involves some system of property rights. Without such a system, we would not be able to define what belongs to each one citizen -the resources that each has to pursue his ends- nor, consequently, to characterize certain actions of others as illicit interventions. The property rights implied by the idea of division of responsibility are, however, too abstract to endorse the conclusion sought by Ripstein, namely, that the place of tort law in Rawls' theory of justice is logically antecedent to the principles chosen in the position original. The idea of the division of responsibility does not, therefore, support the conclusion that tort law is not subject to these principles and their distributive injunctions.

\section{ConClusion}

Ripstein uses three theses to conclude that Rawls' theory of justice assigns a special place to tort law. The first is that Rawls' original position has no justification function, that is, that the justification of the principles in Rawls' theory of justice does not depend on the choices that would be made from the point of view of the original position. The second is that, even if the original position played some justification role, that justification -in light of the characteristics of that position- would be necessarily consequentialist and, therefore, inappropriate to dealing with private law in general and tort law in particular. These first two theses are thus opposed to the conclusion that tort law is subject to the principles of distributive justice-such as the difference principle-which, according to Rawls, would be chosen in the original position. Neither the original position would be able per se to justify these principles, nor would it be an adequate perspective to determine the principles of an area of law with the characteristics of tort law.

${ }^{30}$ Note that the claim that the idea of division of responsibility does not imply that Rawlsian institutions include a system of tort law does not contradict the argument of the previous section. This argument is that the original position is compatible with deontological institutions such as tort law, and not that the original position implies principles that necessarily require institutions with that character. I am grateful to an anonymous reviewer of Revista Chilena de Derecho Privado for urging me to be clearer on this point. 
The third thesis proposes to demonstrate why the place of tort law in Rawls' theory of justice is not that of an area of law designed to address the distributive injunctions of justice as fairness (in particular, the distributive injunctions of the difference principle). Rawls' theory of justice is based on a division of responsibility between social institutions and citizens. According to Ripstein, this division would imply a private law occupied exclusively with ensuring each citizen the use of their resources, ie. those to which each is entitled under fair terms of social cooperation.

This article has sought to demonstrate that these three theses fail. It is inaccurate to say that Rawls' original position is a mere display device, without any justifying force. The principles of justice as fairness are justified because they are the principles that we would choose in the circumstances of the original position. Although the characteristics of this position (that is, the conditions of choice) can be reviewed, such study can only take place for the reasons that are specific to the case -in other words, for the reasons that are consistent with the task of describing a point of view that is suitable for the choice of principles of justice. Therefore, the original position cannot be modified only to provide principles whose justification is completely independent of that position.

The second thesis is mistaken for failing to consider that the principles of Rawls' conception of justice apply only to the basic structure of society, that is, to institutions whose impact on citizens' expectations regarding primary goods is considerable. Thus, subjecting areas of private law, such as tort law, to the principles of justice as fairness does not mean subjecting all these areas to the principles in question. A tort law regime governed by principles of justice like the difference principle could, despite this, maintain the deontological structure -and the centrality of the idea of causality- that traditionally characterizes tort law systems. It is also important to underline, contrary to Ripstein, the restricted sense in which the use of the original position makes justice as fairness a consequentialist conception of justice. It serves as such only in the sense that its principles are chosen according to their consequences for the distribution of primary goods. The principles thus justified, however, can give rise to institutions and rules insensitive to consequences (for example, the rule that the agent causing harm must compensate her victim) both in its content and in the way in which these rules are applied.

Finally, on the division of responsibility thesis, Ripstein is correct to claim that Rawls' conception of justice presupposes certain property rights -rights without which it would not be possible to assign to every citizen the responsibility of pursuing their own ends under institutions that ensure fair terms of social cooperation. Ripstein exaggerates, however, in claiming that these property rights would have to include something 
like a tort law system. The idea that each person has what is her own to pursue her ends remains intelligible even though the resources available to each are not protected by rights to reparation such as those that are usually conferred by tort law rules.

\section{REFERENCES}

Coleman, Jules L. (1988). "The Structure of Tort Law". Yale Law Journal, vol. 97. New Haven, CT.

Freeman, Samuel (2018). Liberalism and Distributive Justice. Nova York: Oxford University Press.

Kordana, Kevin A. y David H. Tabachnick (2006a). "On Belling the Cat: Rawls and Tort as Corrective Justice". Virginia Law Revierw, vol. 92, n. ${ }^{\circ} 7$. Charlottesville, VA

Kordana, Kevin A. y David H. TABAchnick (2006b). "Taxation, the Private law, and Distributive Justice". Social Philosophy and Policy, vol. 23. Cambridge.

Laden, Anthony Simon (2014). "Constructivism as Rhetoric", in Jon Mandle y David A. REIDY (coords.). A Companion to Rawls. Malden, MA: Wiley Blackwell.

Perry, Stephen (2004). "Ripstein, Rawls, and Responsibility". Fordham Law 104 Review, vol. 72, n. ${ }^{\circ}$ 5. New York, NY.

Pogge, Thomas W. (1995). "Three Problems with Contractarian-Consequentialist Ways of Assessing Social Institutions". Social Philosophy and Policy, vol. 12, n. ${ }^{\circ}$ 2. Cambridge,

Rawls, John (1996). Political Liberalism. New York, NY: Columbia University Press.

Rawls, John (1999a). Collected Papers (Samuel Freeman ed.). Cambridge, MA: Harvard University Press.

RAwLs, John (1999b). A Theory ofJustice. 2 ed. rev. Cambridge, MA: Belknap Press.

RAwls, John (2001). Justice as Fairness: A restatement. Cambridge, MA: Belknap Press.

Ripstein, Arthur (2004). "The Division of Responsibility and the Law of Tort". Fordham Law Review, vol. 72, n. ${ }^{\circ}$ 5. New York, NY.

Scheffler, Samuel (2015). "Distributive Justice, the Basic Structure and the Place of Private Law". Oxford Journal of Legal Studies, vol. 35, n. ${ }^{\circ}$ 2. Oxford.

Vallentyne, Peter, Hillel Steiner y Michael Otsuka (2005). "Why Left-Libertarianism is not Incoherent, Indeterminate, or Irrelevant: A Reply to Fried". Philosophy \& Public Affairs, vol. 33, n. ${ }^{\circ}$ 2. Hoboken, NJ.

Zanitelli, Leandro Martins (2019). "Direito Privado e Justiça: o Argumento da Divisão Institucional do Trabalho”. Philósophos, vol. 24, n. ${ }^{\circ}$ 2. Goiânia. 